\begin{tabular}{|c|c|c|c|c|}
\hline$*$ & & AR. & DP. & $\mathrm{Au}$ \\
\hline 54 & $3^{h}$ & $\begin{array}{l}1896.0 \\
8^{\mathrm{m}} 46^{\mathrm{s}} 62\end{array}$ & $\begin{array}{c}1896.0 \\
89^{\circ} 5^{\prime} 8^{\prime} 49^{\prime \prime} 7\end{array}$ & $W_{1} 3^{h} 107$ \\
\hline 55 & & $\begin{array}{l}8 \quad 1.80 \\
1897.0\end{array}$ & $\begin{array}{c}901255.0 \\
1897.0\end{array}$ & Schj. 9 I 7 \\
\hline $5^{6}$ & 3 & 3940.50 & $90 \quad 37 \quad 14.5$ & Paris 4428 \\
\hline
\end{tabular}

\begin{tabular}{|c|c|c|c|}
\hline$*$ & AR. & DP. & Autorite \\
\hline & 1897.0 & 1897.0 & \\
\hline 57 & $3^{\mathrm{h}} 44^{\mathrm{m}} 14^{\mathrm{s}} \cdot 94$ & $90^{\circ} 40^{\prime}$ I $0^{\prime \prime} \mathrm{I}$ & $\mathrm{M}_{1}$ I I I I \\
\hline 58 & $\begin{array}{lll}3 & 47 & 1.89\end{array}$ & $90 \quad 57 \quad 52.4$ & Paris 4540 \\
\hline 59 & $\begin{array}{lll}3 & 54 & 9.95\end{array}$ & 904 I 564 & Schj. I 240 \\
\hline
\end{tabular}

Remarques.

(6) Hébé. Les 6 et 7 Mars l'étoile de comparaison a été observée à la méridienne le jour même.

Comète 1896 VII (Perrine 8 Déc.). Le 30 Décembre le ciel est brumeux. - Le 6 Janvier la comète est ronde avec une condensation au centre donnant l'éclat d'une étoile $12^{\circ}$ grandeur. Son diamètre apparent est d'environ $\mathrm{I}^{\prime} 3 \mathrm{O}^{\prime \prime}$.

Besançon 1897 Janv. 14.

L. F. Gruey.

\title{
Beobachtungen des Encke'schen Cometen 1895 I
}

angestellt am 8zoll. Refractordes astronomischen Observatoriums der k. k. böhm. Universität in Prag.

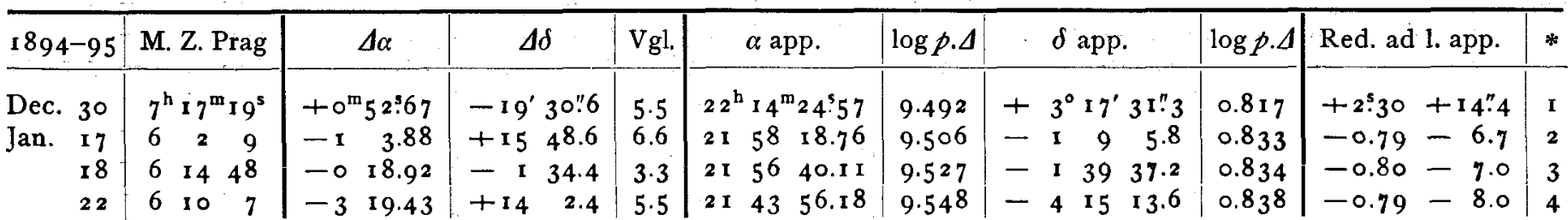

Mittlere Oerter der Vergleichsterne.

\begin{tabular}{|c|c|c|c|}
\hline * & $\alpha \times 894-95.0$ & $\delta \times 894-95.0$ & Autorität \\
\hline I & $22^{\mathrm{h}} 13^{\mathrm{m}} 29^{\mathrm{s}} 60$ & $+3^{\circ} 36^{\prime} 47^{\prime \prime} 5$ & AG. Albany 7746 \\
\hline $\mathbf{2}$ & $21 \quad 59 \quad 23.43$ & -12447.7 & $1 / 3\left(\right.$ Schj. $\left.9003+M_{1} 30166+Y_{3} 9937\right)$ \\
\hline $\begin{array}{l}3 \\
4\end{array}$ & $\begin{array}{lll}2 I & 56 & 20.39 \\
2 I & 47 & 16.50\end{array}$ & $\begin{array}{l}-13755.8 \\
-4298.0\end{array}$ & $\begin{array}{l}1 / 2\left(\mathrm{Gött}_{1} 6072 \cdot 3+\mathrm{M}_{1} 30061\right) \\
\mathrm{Y}_{3} 9^{8} 39\end{array}$ \\
\hline
\end{tabular}

Die Beobachtungen sind am Kreuzstabmikrometer angestellt. Die Reduction besorgte Herr Malir, Assistent des Observatoriums.

Bei den Beobachtungen vom I7., I8. und I9. Januar stand der Comet tief am Horizont und war sehr hell, indem er einem sehr hellen Sternhaufen glich.

Lemberg 1897 Jan. I 5 .

W. Laska.

\section{The Spectrum of $\zeta$ Puppis.}

\section{By Edward C. Pickering.}

The announcement was made in A. N. 3390 that the spectrum of the star $\zeta$ Puppis contained, in addition to the usual series of lines due to hydrogen, a second series of rhythmical lines. A remarkable relation exists between these two series, from which it appears that the second series, instead of being due to some unknown element as was at first supposed, is so closely allied to the hydrogen series, that it is probably due to that substance under conditions of temperature or pressure as yet unknown. The wave lengths of the lines of hydrogen may be computed by the formula

$$
\lambda=3646.1 \frac{n^{2}}{n^{2}-16}
$$

which is the formula of Balmer, slightly modifying the constant term so that the standard wave lengths of Row. land shall be represented, and substituting $1 / 2 n$ for $m$. The wave lengths of the lines of hydrogen may be determined by this formula if we substitute for $n$ the even integers 6 , $8,10,12$, etc.

In the annexed table the values of $n$, the designations of the corresponding lines of hydrogen, their computed wave lengths, their observed wave lengths, and the observed minus the computed values are given in the first five columns. If now we substitute for $n$ the odd integers 5 , $7,9,11$, etc. we obtain the wave lengths of the second series of lines in the spectrum of $\zeta$ Puppis, as is shown in the second part of the table. The sixth column gives the value of $n$, the seventh the corresponding computed wave length, and the eighth and ninth the wave lengths of the lines in $\zeta$ Puppis as derived from two series of measures. 